\title{
Tumor-derived alpha-fetoprotein (tAFP) causes immune and metabolic dysfunction in monocyte- derived dendritic cells
}

\author{
Patricia M Santos*, Angela Pardee, Greg M Delgoffe, Lisa H Butterfield \\ From 30th Annual Meeting and Associated Programs of the Society for Immunotherapy of Cancer (SITC 2015) \\ National Harbor, MD, USA. 4-8 November 2015
}

\section{Background}

Alpha-fetoprotein (AFP) is an oncofetal antigen expressed by over $50 \%$ of hepatocellular carcinoma (HCC) tumors. AFP-L3 is the major isoform present in the serum of HCC patients and is associated with poor patient prognosis. While HCC tumor-derived AFP (tAFP) contains $>80 \%$ of AFP-L3, cord blood serum-derived AFP (nAFP) contains less than $5 \%$ of AFP-L3. Previous studies have proposed an immunoregulatory role for AFP on myeloid cells including dendritic cells (DC).

\section{Methods}

Therefore, to test the specific effect of nAFP and tAFP on DC differentiation in vitro, peripheral blood monocytes from healthy donors were cultured in the presence of nAFP or tAFP, and DC phenotype and function was assessed after 5 days. We have previously shown that monocytes cultured in vitro in the presence of tAFP differentiated into DC that retained a monocyte-like morphology, had decreased expression of surface DC maturation markers, exhibited limited production of inflammatory cytokines, and failed to induce robust $\mathrm{T}$ cell proliferative responses. Here, we investigate the mechanisms of tAFPinduced suppressive effects on monocyte-derived DC. Specifically: i) CD1 family surface expression, ii) chemokine production, and iii) DC metabolism.

\section{Results}

Our results show that 5 days after culture, the mRNA and surface expression of CD1a, CD1b, CD1c and CD1d are reduced in $\mathrm{nAFP}-\mathrm{DC}$ and are further reduced in tAFP-DC. We also show that tAFP-DC had decreased secretion of chemokines CCL1, CCL2, CCL3, CCL4,

University of Pittsburgh, Pittsburgh, PA, USA
CCL17, CCL20 and CCL22 in day 6 and/or day 7 supernatants on a per cell basis. Most importantly, we observe reduced mitochondrial mass and a significant defect in mitochondrial oxidative phosphorylation and inhibition of glycolysis in tAFP-DC compared to OVA-DC or nAFP-DC.

\section{Conclusions}

Collectively, these data show profound negative effects of tAFP on DC function. These results help explain some of the immune suppression observed in AFP+ HCC patients and may lead to novel therapeutic approaches to reverse these immunosuppressive effects to improve DC function and enhance anti-HCC immunity.

Published: 4 November 2015

doi:10.1186/2051-1426-3-S2-P210

Cite this article as: Santos et al:: Tumor-derived alpha-fetoprotein (tAFP) causes immune and metabolic dysfunction in monocyte-derived dendritic cells. Journal for ImmunoTherapy of Cancer 2015 3(Suppl 2):P210.

Submit your next manuscript to BioMed Central and take full advantage of:

- Convenient online submission

- Thorough peer review

- No space constraints or color figure charges

- Immediate publication on acceptance

- Inclusion in PubMed, CAS, Scopus and Google Scholar

- Research which is freely available for redistribution 